\title{
Screening of kidney disease in HIV infected hospitalised patients
}

\author{
Sanjeev Kumar ${ }^{1}$, Arvind Trivedi $^{2}$, G.K. Aneja ${ }^{3}$, V Atam ${ }^{4}$, T.V.S. Arya ${ }^{5}$, Vandana ${ }^{6}$, Pradeep Kumar $^{7}$ \\ ${ }^{1}$ Senior Resident, Department of Medicine, K GM U, Lucknow, ${ }^{2}$ Professor, Department of Medicine, LLRM, Medical College, Meerut, \\ ${ }^{3}$ Professor and Head, Department of Medicine, LLRM, Medical College, Meerut, ${ }^{4}$ Professor, Department of Medicine, K GM U, Lucknow, \\ ${ }^{5}$ Professor, Department of Medicine, LLRM, Medical College, Meerut, ${ }^{6}$ Junior Resident, Department of Obstetrics and Gynecology, K GM U, \\ Lucknow, ${ }^{7}$ Professor, Department of Physiology, K GM U, Lucknow
}

\section{A B S T R A C T}

Objectives: To study the renal disease in newly diagnosed HIV infected hospitalized patients and to look for possible correlation of CD4 count with prevalence of renal disease. Materials and Methods: The prospective study was conducted in Department of Medicine/Endocrinology in tertiary care health center in western U.P during the study period of one year. The patients were evaluated clinically and biochemically after obtaining the informed consent. Result: The study was conducted on 100 HIV/AIDS patients, out of which 68 (68\%) were males and $32(32 \%)$ females with a Highest incidence of HIV/AIDS (51\%) in the age group of $25-35$ years. Microalbuminuria was present in 20 (20\%) HIV patients with majority (60\%) being in the age group 25-35 years. Prevalence of microalbuminuria among males was $55 \%$ and among females $45 \%$. Microalbuminuria was further evaluated by calculating the ratio of microalbumin to urinary creatinine, $83 \%$ patient had ratio $>10 \mathrm{mg} / \mathrm{mmol}$ and $17 \%$ had this ratio $<10 \mathrm{mg} / \mathrm{mmol}$. The ratio of microalbumin to urinary creatinine $>10 \mathrm{mg} / \mathrm{mmol}$ was $60 \%$ in age $25-35$ year, $25 \%$ in the age group of $36-45$ year followed by $15 \%$ in the age group of 45-55 year patients. Chi-square test was used to calculate the significance of the correlation between CD4 counts with the presence of microalbuminuria in HIV patients. There was a significant correlation between CD4 count $<200 / \mu \mathrm{L}$ and presence of microalbuminuria ( $p=0006)$. Statistically significant proteinuria (30-300 mg/24 hour) was found in 15 patients with CD4 count $<200 / \mu \mathrm{L}$ of those patients found positive for microalbuminuria. Protein/ creatinine ratio was $<0.2$ in 18 patients, 2 had ratio in the range of 0.2-3.5 and none in the nephrotic range (>3.5). Conclusion: Study evaluation shows that there is statistically significant microalbuminuria in HIV/AIDS infected patients and this is more prevalent in patients with CD4 count $<200 / \mu \mathrm{L}$ as compared to patients with CD4 count $>200 / \mu \mathrm{L}$ in keeping with previous studies. The routine laboratory measurements like serum creatinine and proteinuria fail to recognize the patients with early renal involvement. In view of the high prevalence of renal dysfunction among hospitalized HIV infected patients, it is recommended to use microalbuminuria as routine screening tests in those who are HIV positive.

Key words: Renal disease, Microalbuminuria, HIV infection, Serum creatinine

\section{Access this article online}

Website:

http://nepjol.info/index.php/AJMS DOI: 10.3126/ajms.v6i3.11376

\section{INTRODUCTION}

Since the detection of first HIV patient in 1983 HIV and AIDS has spread very rapidly to take the shape of pandemic. According to the UNAIDS report 2013, there were 35.3 (32.2-38.8) million patients living with HIV across the globe. ${ }^{1}$ The number of new infection showed a reduction of $33.3 \%$ in 2012 from 2001. The mortality has declined in 2012 to 1.6 (1.4-1.9) million as compared to $2.3(2.1-2.6)$ million in $2005 .{ }^{1}$

The Government of India estimated that about 2.40 million Indians were living with HIV (1.93-3.04 million) with an adult prevalence of $0.31 \%(2009) .{ }^{2}$ Children ( $\left.<15 \mathrm{yrs}\right)$ accounted for $3.5 \%$ of all infections. While $83 \%$ were the in age groups 15-49 years. Of all HIV infections, 
39\% (930,000) were among women. India's highly heterogeneous epidemic was largely concentrated in only few states - In the industrialized south and west, and in the north-east. Four high prevalence states of South India (Andhra Pradesh-500,000, Maharashtra-420,000, Karnataka-250,000, Tamil Nadu-150,000) accounted for $55 \%$ of all HIV infections in the country. West Bengal, Gujarat, Bihar and Uttar Pradesh were estimated to have more than 100,000 PLHA each and together account for another $22 \%$ of HIV infections in India. ${ }^{2}$

Survival among persons with HIV infection has improved significantly over the last decade. ${ }^{3}$ Concurrent with the improvements in morbidity and mortality, there has been an increase in deaths among HIV infected patients attributed to kidney disease. ${ }^{3}$

As a result, there has been increasing focus in research and clinical care on kidney conditions, which has improved our understanding of their pathogenesis as long-term complications of HIV infection. Among HIV infected persons, the presence of microalbuminuria has been linked to CKD (chronic kidney disease), ESRD (end stage renal disease), new AIDS defining illness and mortality. ${ }^{4}$ The spectrum of renal involvement in HIV positive patients ranges from mild fluid and electrolyte disorders to acute renal failure and HIV associated nephropathy (HIVAN) leading thereby to end-stage renal disease (ESRD). ${ }^{4}$

HIVAN is the third leading cause of ESRD in AfricanAmericans between the age of 20 and 64 and the most common cause of ESRD in HIV-1 seropositive patients. ${ }^{5}$ Patients typically present with renal insufficiency accompanied by proteinuria that is usually in the nephrotic range. ${ }^{5}$ Despite the presence of heavy proteinuria, peripheral edema is uncommon. Hypertension is also surprisingly rare in most patients of HIVAN.

There is scarcity of Indian studies as far as the renal spectrum in HIV is concerned.

\section{Aims and Objectives}

This is a cross section observational study conducted with the following objectives:

1. To study the presence of renal diseases in newly diagnosed HIV infected hospitalized patients.

2. To look for possible correlation of CD4 count with prevalence of renal disease.

\section{MATERIALS AND METHODS}

The present cross section observational study was conducted on $100 \mathrm{HIV}$ infected hospitalized patients in a tertiary care hospital over a period of one year. A written and informed consent was taken from the subjects prior to the study. Screening tests employed were Direct Sandwich Elisa Test Method ( $3^{\text {rd }}$ generation) and Combaids-RS Test for Detecting HIV-1 and 2. The subjects underwent various laboratory investigations like complete blood count, urine examination, urea, creatinine, Serum proteins, Blood Urea, blood sugar, $24 \mathrm{hr}$, Chest X-Ray, USG Abdomen KUB, Microalbumin urine test (MICRAL test), a semiquantitative immunological method for the detection of urinary albumin, was used in this study. Glomerular filtration rate (GFR) was derived from creatinine clearance calculated by Cockcroft Gualt formula. CD4 T lymphocyte count was measured by using BD True COUNT Method. Inclusion criteria were age $>25$ years, absence of severe cardiac disease, absence of urinary tract infection, no drug use that could interfere in urinary creatinine excretion, absence of pregnancy, non diabetic HIV patients. Exclusion criteria were patient not giving consent for the study, mentally subnormal, and not fulfilling inclusion criteria.

\section{Statistical Analysis}

Continuous data were summarized as Mean \pm SD while discrete (categorical) in number and percentage. Continuous two independent groups were compared by parametric independent Student's test and the significance of parametric t test was also validated with nonparametric alternative Mann-Whitney U test, where appropriate. Discrete (categorical) groups were compared by chi-square $\left(\chi^{2}\right)$ test. Predictors of final outcome were evaluated by using multivariate logistic regression analysis. A two-sided $(\alpha=2) \mathrm{p}$ values less than $0.05(\mathrm{p}<0.05)$ was considered statistically significant. All analyses were performed on STATISTICA data analysis software system version 6.0 (for Windows). Tulsa, OK: StatSoft.Inc; 2000.

\section{RESULTS}

The present study was conducted on $100 \mathrm{HIV} /$ AIDS patients, out of which $73(73 \%)$ were males and 27 (27\%) females. More than half $(56 \%)$ of the patients were in

\begin{tabular}{|c|c|c|c|c|c|c|}
\hline \multirow{2}{*}{$\begin{array}{l}\text { Age } \\
\text { (in years) }\end{array}$} & \multicolumn{2}{|c|}{ Male } & \multicolumn{2}{|c|}{ Female } & \multicolumn{2}{|c|}{ Total } \\
\hline & No. & $\%$ & No. & $\%$ & No. & $\%$ \\
\hline $25-35$ & 41 & 73.2 & 15 & 26.8 & 56 & 56.0 \\
\hline $36-45$ & 18 & 62.1 & 11 & 37.9 & 29 & 29.0 \\
\hline$>45$ & 14 & 93.3 & 1 & 6.7 & 15 & 15.0 \\
\hline Total & 73 & 73.0 & 27 & 27.0 & 100 & 100.0 \\
\hline
\end{tabular}

Chi-square $=4.90, p=0.08$ (between age and gender) 
the age group 25-35 years (Table 1). The distribution of biochemical parameters is depicted in the Table 2. The average $\mathrm{Hb}$ was $10.51( \pm 2.02)$ whereas the mean serum creatinine was $1.28( \pm 0.61)$. The prevalence of microalbuminuria was found to be $25 \%$ (Table 3 ) The distribution of HIV/AIDS patients according to EGFR staging is depicted in the Table 4. About one third of the patients were in stage II $(37 \%)$ and III (35\%). However, $15 \%$ were in stage IV and $13 \%$ in stage I. The association of microalbuminuria with age of the patients is presented in the Table 5. The prevalence of microalbuminuria was insignificantly $(\mathrm{p}>0.05)$ higher among the patients of $36-45$ years $(27.6 \%)$ compared with $25-35(26.8 \%)$ and $>45(13.3 \%)$ years. The correlation of CD4 cell counts with the presence of microalbunuria is given in the

\begin{tabular}{lc}
\multicolumn{2}{l}{ Table 2: Biochemical distribution of HIV/AIDS } \\
patients \\
\hline Biochemical parameters & Mean \pm SD \\
\hline $\mathrm{Hb}$ & $10.51 \pm 2.02$ \\
$\mathrm{TLC}$ & $7933.52 \pm 3072.86$ \\
PC & $1.93 \pm 0.60$ \\
S.Urea & $34.72 \pm 20.84$ \\
S.Creat & $1.28 \pm 0.61$ \\
B.Sugar. & $130.41 \pm 8.05$ \\
Urine 24 hour & $69.57 \pm 97.92$ \\
Na & $134.19 \pm 9.11$ \\
K & $3.20 \pm 0.58$ \\
CD4 count & $237.59 \pm 99.69$ \\
EGFR & $60.92 \pm 27.83$ \\
\hline
\end{tabular}

\begin{tabular}{lcc}
$\begin{array}{l}\text { Table 3: Distribution of HIVIAIDS patients } \\
\text { according to microalbuminuria }\end{array}$ \\
\hline \multicolumn{3}{c}{ No. $(\mathbf{n = 1 0 0 )}$} \\
\hline Positive & 25 & $\%$ \\
Negative & 75 & 25.0 \\
\hline
\end{tabular}

\begin{tabular}{|c|c|c|}
\hline Stage of EGFR & No. $(n=100)$ & $\%$ \\
\hline 1 & 13 & 13.0 \\
\hline II & 37 & 37.0 \\
\hline III & 35 & 35.0 \\
\hline IV & 15 & 15.0 \\
\hline
\end{tabular}

\begin{tabular}{l}
$\begin{array}{l}\text { Table 5: Association of microalbuminuria with } \\
\text { age of the patients }\end{array}$ \\
\begin{tabular}{lccc} 
Age in & $\begin{array}{c}\text { No. of } \\
\text { patients }\end{array}$ & $\begin{array}{c}\text { No. with } \\
\text { microalbuminuria }\end{array}$ & $\%$ \\
years & 56 & 15 & 26.8 \\
\hline $25-35$ & 29 & 8 & 27.6 \\
$36-45$ & 15 & 2 & 13.3 \\
$>45$ & &
\end{tabular} \\
\hline Chi-square $=1.28, p=0.52$
\end{tabular}

Table 6. The prevalence of microalbunuria was among $35.7 \%$ in the patients of CD4 cell count $<200 / 1$ and it were $17.2 \%$ in the patients of CD4 cell count $\geq 200 / 1$. However, this correlation was statistically significant $(\mathrm{p}=0.03)$.

There was negative poor correlation between CD4 with serum creatinine and 24 hour urine protein (Table 7 ).

\section{DISCUSSION}

HIV associated nephropathy; the most common renal disease in HIV patients was first described in 1984. ${ }^{6,7}$ Most patients present with nephrotic syndrome, progressive loss of renal function and without treatment progress to ESRD within months. ${ }^{8}$ The present study was undertaken to detect the prevalence of microalbuminuria in patients who were positive for HIV irrespective of the stage of illness. Out of these, $73 \%$ were males and $27 \%$ females with male: female ratio of $2.7: 1$. In a large Indian study done in Pune involving 2801 subjects over a period of 2 years, Ghate et al. ${ }^{9}$ reported male:female ratio of 2.22:1. In another Indian study, Kumarasamy et al. ${ }^{10}$ reported that out of $594 \mathrm{HIV} /$ AIDS patients, 72.9\% were males and $27.1 \%$ females, male: female ratio being 2.6:1, which is consistent with the present study.

Highest incidence of HIV/AIDS (51\%) was found in the age group of 25-35 years in the present study, followed by $29 \%$ in 36-45 years age group. When the two age groups were clubbed from age 26 to 45 years, the incidence came out to be $81.47 \%$. In a study by Ghate et al, ${ }^{6} 88.1 \% \mathrm{HIV}$ positive patients were in the age group of 21 to 40 years, which is almost consistent with the present study. Another Indian Study done in Jammu was conducted on 108 HIV/AIDS patients, out of which 77 (71\%) were males

\begin{tabular}{|c|c|c|c|c|c|}
\hline \multirow{3}{*}{$\begin{array}{l}\text { CD4 cell } \\
\text { count }\end{array}$} & \multirow{3}{*}{$\begin{array}{c}\text { No. of } \\
\text { patients }\end{array}$} & \multicolumn{4}{|c|}{ Microalbunuria } \\
\hline & & \multicolumn{2}{|c|}{ Positive } & \multicolumn{2}{|c|}{ Negative } \\
\hline & & No. & $\%$ & No. & $\%$ \\
\hline$<200 / \mu l$ & 42 & 15 & 35.7 & 27 & 64.3 \\
\hline$\geq 200 / \mu \mathrm{l}$ & 58 & 10 & 17.2 & 48 & 82.8 \\
\hline
\end{tabular}

\begin{tabular}{|c|c|c|}
\hline & CD4 (r) & $p$-value \\
\hline Serum creatinine & -0.12 & 0.21 \\
\hline 24 hour urine protein & -0.15 & 0.13 \\
\hline
\end{tabular}


and $31(29 \%)$ females with a male: female ratio of $2.48: 1$ (Table 1). ${ }^{11}$ Highest incidence of HIV/AIDS (55.56\%) was found in the age group of 26-35 years, followed by $25.93 \%$ in $36-45$ years.

In our study, prevalence of microalbuminuria was observed in $25 \%$ patients after all $100 \mathrm{HIV} /$ AIDS patients were screened for the presence of microalbuminuria. In a cross sectional study Lynda et al. demonstrated microalbuminuria in 11\% of HIV infected patients while other past three studies showed striking high prevalence of microalbuminuria of $19 \%, 30 \%$ and $34 \%$ in HIV infected patients. ${ }^{12}$

However, Busch et $\mathrm{al}^{8}$ found $13 \%$ of the $90 \mathrm{HIV}$ infected patients with an albumin excretion $>20 \mathrm{mg} /$ liter; Verma et $\mathrm{al}^{13}$ reported prevalence of $17.6 \%$ among 142 HIV patients over a 4 year period. All 20 patients who tested positive for presence of microalbuminuria were further evaluated by 24 hour urinary protein evaluation and only 2 patients had proteinuria in the range of $30-300 \mathrm{mg} / 24$ hour. There was no patient with proteinuria $>300 \mathrm{mg} / 24$ hour (nephrotic range). Further evaluation by urinary microalbumin to creatinine ratio on a spot sample of urine supported present study's finding of microalbuminuria in these patients. Seventeen patients had microalbumin: creatinine ratio $>10 \mathrm{mg} / \mathrm{mmol}$ and $3 \mathrm{had}$ this ratio $<10 \mathrm{mg} / \mathrm{mmol}$.

Mean CD4 cell count was calculated in patients with positive microalbuminuria test and 10 patients had mean CD 4 cell counts $>200 / \mu \mathrm{L}$, while 15 patients had mean CD 4 counts $<200 / \mu \mathrm{l}$, average CD 4 cell counts being $221.27 / \mu \mathrm{l}$ and $119.89 / \mu \mathrm{l}$ respectively. In previous studies also, Szczech et al $^{14}$ found decreased CD4 lymphocyte cell counts and increased HIV-RNA levels as predictors of proteinuria. Atta et $\mathrm{al}^{15}$ found that patients with HIV associated nephropathy had a significantly lower CD4 cell counts $(158 / \mu \mathrm{l}$ versus $349 / \mu \mathrm{l} ; \mathrm{p}<0.01)$ at the time of biopsy. Subclinical dysfunction is not uncommon in HIV positive patients and many of these patients with incipient nephropathy are not detected by routine laboratory tests.

HIV infection appears to be a risk factor for developing chronic kidney disease. Even in patients with normal kidney function, the presence of proteinuria may indicate early kidney disease. If initial urine analysis results are normal, annual follow-up urine analysis are recommended to screen for newly developed kidney damage for the following groups, which are at higher risk for the development of proteinuria and poor renal outcome - African-American persons, patients with diabetes, patients with hypertension, patient with hepatitis $\mathrm{C}$ virus co-infection and patients with HIV-RNA levels $>4000$ copies/L or absolute CD 4 lymphocyte counts $<200 / \mu \mathrm{L}$. An estimate of creatinine clearance for GFR is also recommended annually to screen for renal dysfunction that may develop overtime and that may herald worse overall prognosis. Recent reports have suggested that the baseline presence of proteinuria with or without concomitant elevations in the serum creatinine level is a sensitive prognosticator of the eventual development of chronic kidney disease. ${ }^{11}$ Main limitations of the present study were that firstly HIV-RNA levels would not be performed due to the financial constraints and lack of the facility in the present institution. Secondly, those patients whose urine tested for positive for microalbuminuria could not be further evaluated due to absence of proper set-up for renal biopsy in the hospital.

\section{REFERENCES}

1. UNAIDS (2013) Report on the global HIV AIDS epidemic 2013. Available: http://www.unaids.org/en/media/unaids/ contentassets/documents/epidemiology/2013/gr2013/unaids_ global_report_2013_en.pdf

2. National AIDS Control Organization. Technical Report India HIV Estimates 2008-2009 National Institute of Medical Statistics, ICMR. India: Ministry of Health \& Family Welfare, 2010.

3. Montaner JS, Wood E, Kerr T, Lima V, Barrios R, Shannon K, et al. Expanded highly active antiretroviral therapy coverage among HIV-positive drug users to improve individual and public health outcomes. J Acquir Immune Defic Syndr 2010; 55(Suppl. 1):S5-S9.

4. Jotwani V, Li Y, Grunfeld C, Choi Al and Shlipak MG. Risk Factors for ESRD in HIV-Infected Individuals: Traditional and HIV-Related Factors. Am J Kidney Dis 2012; 59(5):628-635.

5. Bigé N, Lanternier F, Viard JP, Kamgang P, Daugas E, Elie C, et al. Presentation of HIV-associated nephropathy and outcome in HAART-treated patients. Nephrol Dial Transplant 2012; 27: 1114-1121.

6. Ghate MV, Divekar AD, Risbud AR, Thakar MR, Brahme RG and Mehendale SM. Changing trends in clinical presentations in referred human immunodeficiency virus infected person in Pune, India. JAPI 2002; 50: 671-673.

7. Kumarasamy N, Solomon S, Flanigan TP, Hemalatha R, Thyagarajan SP and Mayer $\mathrm{KH}$. Natural history of immunodeficiency virus disease in Southern India. Clin Infect Dis 2003; 36: 79-85.

8. Vali PS, Ismal K, Gowrishankar S and Sahay M. Renal disease in human immunodeficiency virus - Not just HIV-associated nephropathy. Indian J Nephrol 2012; 22: 98-102.

9. Szczech LA, Gange SJ and Van Der HC, Predictors of proteinuria and renal failure among women with HIV infection. Kidney International 2002; 61: 195-202.

10. Gardner LI, Holmberg SD, Williamson JM, Szczech LA, Carpenter CC, Rompalo AM, et al. HIV Epidemiology Research Study Group. Development of proteinuria or elevated serum creatinine and mortality in HIV infected women. J AIDS 2003; 32: 203-209. 
11. Singh JP, Kohli S, Jamwa S, Sharma R, Hamid S and Raina S. Prevalence of Microalbuminuria and Proteinuria In Patients of HIVIAIDS in Jammu. JK Science 2011; 13:2.

12. Szczech LA, Grunfeld G, Scherzer R, Canchola JA, van der Horst $\mathrm{C}$, Sidney S, et al. Microalbuminuria in HIV infection. AIDS 2007; 21: 1003-1009.

13. Varma PP, Prasher PK, Deshpande GU, Mani NS, Nema SK and Sayal SK. Spectrum of renal lesions in HIV patients. J Assoc
Physicians India 2000;48: 1151-1154.

14. Szczech LA, Hoover DR, Feldman JG, Cohen MH, Gange SJ, Goozé $L$, et al. The association between renal disease and outcome among HIV infected women taking ART. Clin Infections Dis 2004; 39: 1199-1206.

15. Atta MG, Choi MJ and Longenecker JC. Nephrotic range proteinuria and CD4 count as non-invasive indicators of HIV associated nephropathy. Am J Med 2005; 118: 1288.

Authors Contribution:

SK - Contributed to the original idea, designed the study, enrolled the patients, collected the data and analysed, prepared the manuscript and reviewed the manuscript; AT - Conceived hypothesis, designed study, patient enrolment, data collection, data analysis, preparing of manuscript and reviewing the manuscript; GKA - Contributed to the study design, data analysis, preparing of manuscript and reviewing the manuscript; VA - Contributed to patient enrolment and data collection; TVSA - Contributed to the data collection, data analysis and preparing of manuscript; V and PK - Contributed to data analysis, preparing of manuscript and reviewing the manuscript.

Source of Support: Self, Conflict of Interest: None declared. 